\title{
А.В. Плотникова
}

НП «Научно-образовательный центр «Инновационные горные технологии»

\section{РЕСУРСОСБЕРЕГАЮЩАЯ ТЕХНОЛОГИЯ ПЕРЕРАБОТКИ ТРУДНООБОГАТИМЫХ РУД НА ОСНОВЕ МАГНИТНО-ИМПУЛЬСНОГО ВОЗДЕЙСТВИЯ"}

\begin{abstract}
Аннотация. Рассмотрено применение магнитно-импульсной обработки железных руд с целью снижения энергоемкости помола за счет лучшего раскрытия рудной фазы при более низком содержании фракции заданной крупности.
\end{abstract}

Ключевые слова: железная руда, магнитно-импульсная обработка, раскрытие рудной фазы, готовый класс, энергоемкость, качество концентрата.

\section{RESOURCE-SAVING TECHNOLOGY OF PROCESSING DIFFICULT BENEFICATION ORES ON THE BASIS OF MAGNETIC-IMPULSE IMPACTS}

\begin{abstract}
Described the use of magnetic pulse treatment of iron ore, for reducing the energy consumption of disintegration of ore due to better discovery of grain component wen the content of small particles is lower.
\end{abstract}

Keywords: iron ore, magnetic-pulse treatment, the disclosure of ore phase, fine fraction, energy intensity, the quality of the concentrate.

Самым энергоемким и дорогостоящим процессом при добыче и обогащении минерального сырья является их разрушение. Так, например, на железорудных горно-обогатительных комбинатах России на долю этого процесса приходится $70 \%$ всех энергозатрат ( 230 кВт·ч/т руды) [1].

Одним из перспективных направлений по снижению энергоемкости измельчения руды и повышению извлечения полезного компонента является ее разупрочнение путем магнитно-импульсной обработки (МИО) [2].

При сопоставимой крупности измельчения рудные и нерудные минералы труднообогатимых руд раскрываются в меньшей степени по отношению к средне- и легкообогатимым рудам. Для труднообогатимых руд следует отметить более низкое количество свободных рудных зерен и повышенное количество вкрапленников. Это может быть обусловлено как малым размером зерен полезного компонента, так и высокой прочностью границ раздела рудной и нерудной фаз [3].

При электромагнитом воздействии импульсное магнитное поле распространяется по всему объему руды. При наличии в руде минералов пьезоэлектриков (например кварца) или магнитных зерен (например магнетита), МИО способствует проявлению эффектов магнитострикции и обратного пьезоэффекта. При этом, за счет неоднородности магнитно-электрических и механических свойств минералов, возникает концентрация механических напряжений, способствующих развитию дефектов на границе фаз [4].

\footnotetext{
* Работа выполнена при поддержке Фонда содействия развитию малых форм предприятий в научно-технической сфере.
}

На магнетитовых рудах были проведены исследования с целью выявления степени влияния МИО на измельчаемость и обогатимость этих руд.

В процессе испытаний железная руда подвергалась МИО с последующим измельчением в лабораторной мельнице фиксированное время до содержания класса - 0,074 мм (ориентировочно 85 - 90 \%) с дальнейшим обогащением на трубке Дэвиса. Далее проводился сравнительный анализ с результатами контрольного эксперимента, проводимого в идентичных условиях без использования МИО.

Результаты испытаний показали, что при выбранных режимах МИО прирост фракции - 0,074 мм составил менее, чем $1 \%$, что эквивалентно относительному приросту производительности мельницы по данному классу менее чем на $1,5 \%$.

Такой незначительный результат по влиянию МИО на измельчаемость руды не имеет практической ценности. Однако в пробах, подверженных МИО, содержание железа в магнитной фракции, полученной после лабораторного обогащения, увеличилось с 63,5 до $65,2 \%$ что эквивалентно сокращению времени измельчения и затрат энергии на $12 \%$.

Учитывая, что практическая задача снижения удельных затрат энергии при обогащении заключается в повышении производительности фабрики по руде при сохранении энергетических затрат и качества конечного концентрата, можно сделать заключение, что использование МИО может обеспечить снижение удельной энергоемкости измельчения до $12 \%$. При этом такой критерий, как производительность мельницы по классу заданной крупности, становится незначимым. 
На основании вышеизложенного можно сделать вывод, что использование МИО железных руд может обеспечить снижение удельной энергоемкости помола до $12 \%$ за счет лучшего раскрытия рудной фазы при более низком содержании фракции заданной крупности.

\section{БИБЛИОГРАФИЧЕСКИЙ СПИСОК}

1. Гончаров С.А., Ананьев П.П., Иванов В.Ю. Разупрочнение горных пород под действием импульсных электро- магнитных полей. - М.: Изд-во Московского государственного горного университета, 2006. - $91 \mathrm{c}$.

2. Ч ан тур и я В.А. // Горный журнал. 2007. № 2. С. 2 - 9.

3. Ананьев П.П., Головин Ю.И., Ермаков С.В. и др. // Горный информационно-аналитический бюллетень. 2013. № 2. С. $68-70$.

4. Гончаров С.А., Ананьев П.П., Плотникова А.В. // Горный журнал Казахстана. 2013. № 7. С. $18-20$.

(C) 2013 г. А.В. Плотникова Поступила 9 сентября 2013 г. 